Primljen / Received: 15.10.2012.

Ispravljen / Corrected: 9.6.2013.

Prihvaćen / Accepted: 14.6.2013.

Dostupno online / Available online: 10.7.2013.

\section{Risk identification in landslide monitoring}

\section{Authors:}

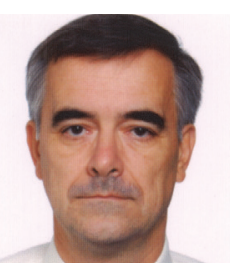

Zlatko Mihalinec, MSc. CE Institut IGH d.d., Zagreb zlatko.mihalinec@igh.hr

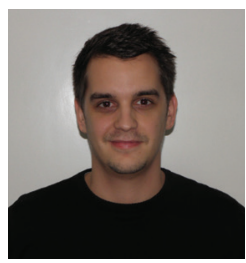

Mario Bačić, mag.ing.aedif. University of Zagreb Faculty of Civil Engineering Department for Geotechnical Engineering mbacic@grad.hr

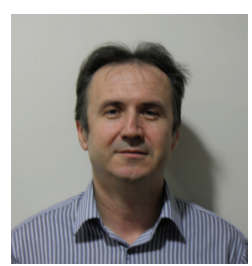

Prof. Meho Saša Kovačević, PhD. CE. University of Zagreb

Faculty of Civil Engineering

Department for Geotechnical Engineering msk@grad.hr

\section{Zlatko Mihalinec, Mario Bačić, Meho Saša Kovačević}

Subject review

\section{Risk identification in landslide monitoring}

Landslide monitoring has an important role in the understanding of the landslide process, which is especially important in urban areas where landslide activation may directly or indirectly endanger human lives and cause material damage. Potential risk sources in landslide monitoring are identified in the paper, and terms the measurement purpose, measured parameters, measuring equipment, and measurement results, are explained. The role of landslide monitoring in urban areas is presented using as an example a well documented landslide Grmoščica in Zagreb.

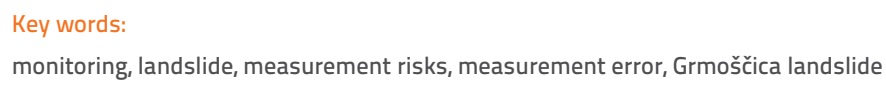

Pregledni rad

\section{Identifikacija rizika pri monitoringu klizišta}

Monitoring klizišta ima značajnu ulogu u razumijevanju procesa klizanja, što je naročito važno u urbanim sredinama gdje aktiviranje klizišta može posredno ili neposredno ugroziti živote ljudi i nanijeti materijalne štete. U radu se identificiraju potencijalni izvori rizika pri monitoringu klizišta, te se objašnjavaju pojmovi svrhe mjerenja, mjernih veličina, mjerne opreme i rezultata mjerenja. Na primjeru dobro dokumentiranog klizišta Grmoščica u Zagrebu prikazat će se uloga monitoringa klizišta u urbanim sredinama.

Ključne riječi:

monitoring, klizište, rizici mjerenja, pogreška mjerenja, klizište Grmoščica

Übersichtsarbeit

Zlatko Mihalinec, Mario Bačić, Meho Saša Kovačević

\section{Identifikation von Risiken beim Monitoring von Erdrutschen}

Die Überwachung von Erdrutschen spielt eine bedeutende Rolle für das Verständnis von Erdrutschprozessen, insbesondere in städtischen Gebieten, in denen durch die Bewegung von Erdmassen Menschenleben direkt oder indirekt gefährdet werden oder Sachschäden verursacht werden können. In dieser Arbeit werden potenzielle Risikoquellen beim Monitoring von Erdrutschen identifiziert und Begriffe erläutert, die sich auf den Zweck der Messungen, Messwerte, Messtechniken und Messergebnisse beziehen. Am Beispiel des gut dokumentierten Erdrutsches Grmoščica in Zagreb wird die Bedeutung der Überwachung von Erdrutschgebieten im städtischen Umfeld dargestellt. 


\section{Introduction}

The occurrence of landslide, i.e. movement of soil mass along one or several slip planes, is not a rare phenomenon in urban areas. When a landslide is activated in an urban area, it can directly or indirectly endanger human lives and cause material damage. This is why it has to be kept under control and improved whenever possible. Understanding the landslide process and being able to simplify it effectively demands the interpretation of numerous processes and activities including geomorphology, hydrology, geology, hydrogeology, geotechnical properties of the area under study, geotechnical model, analysis of seepage, analysis of stability and deformation, and risk assessment and risk mitigation [1]. A constant improvement in all these areas has been noted in recent years. New tools are being used to define properties of landslide locations, and the range of geotechnical models that can be successfully applied in this area has grown considerably. In fact, the capacity to analyse nowdays often exceeds the capacity to characterise. Risk assessment and management of slopes are developing rapidly as a useful tool for dealing with landslides, both locally and regionally. However, uncertainties are still present in geotechnical practice and numerous examples of unanticipated behaviour of geotechnical structures, often with unwanted consequences, have been registered [2]. It should be noted that a landslide is a "living organism" and adjustment to its behaviour is necessary. The role of monitoring is of crucial significance in this respect. Monitoring is the basis for introducing landslide activity control systems and for deciding on measures to be taken depending on actual situation on the landslide [3].

The identification of possible sources of risk during measurements plays an important role in the proper landslide monitoring process. The following questions must be asked to properly identify the risks: a) Why conduct measurements? $\rightarrow$ defines the "measurement purpose"

b) What should be measured? $\quad \rightarrow$ defines "measurement parameters"

c) What should be used for measuring? $\rightarrow$ defines "measuring equipment"

d) What has been measured? $\quad \rightarrow$ defines "measurement results"

Sources of risk during landslide monitoring are contained within the above mentioned four factors, which will be presented and analyzed in the following sections.

\section{Measurement purpose}

On landslide locations, monitoring is conducted in order to investigate, or in order to anticipate and warn [4]. Geotechnical investigations on landslides are conducted in order to define properties of the landslide and circumstances under which it was activated. This must be done so that geotechnical models can be made for analyses and calculations aimed at defining appropriate improvement measures. After the study of basic geotechnical properties of the area, it is necessary to define, for each landslide, its boundaries, sliding direction and depth, displacement value and displacement rate, groundwater level, piezometric pressures on the slip plane, and strength parameters on the slip plane. All of the above, except strength parameters which are defined through laboratory testing, can be determined through monitoring as a part of geotechnical investigations works. The monitoring for investigations does not end after collection of landslide data during geotechnical investigations works and geotechnical model preparation. In fact, in order to monitor the condition of the landslide and structures constructed for its improvement, and to compare the anticipated and actual behaviour of the landslide and improvement structures, the monitoring for investigations is also conducted during landslide improvement works, and also after the end of landslide improvement. Results of monitoring conducted during improvement works can immediately be used for interactive design $[5,6]$. The comparison of behaviour anticipated at the design stage with actual behaviour determined by monitoring enables designers to check accuracy of numerical methods and geotechnical models $[7,8]$. Monitoring after improvement is conducted in order to check whether improvement activities have been successful.

The motivation behind development of monitoring for the purpose of anticipation and warning is the wish to prevent, or at least mitigate, by timely interventions, possible fatalities and damage due to landslide activation. The factor that enables practical application and success of monitoring for anticipation and warning is the development of technologies that are used to detect and monitor displacements in distant and large areas either in real time or in quasi-real time. This type of monitoring is conducted on registered landslides and in landslide prone areas, where it is introduced as an early warning system. The need to introduce a warning system is also present on old temporarily calm landslides on which, due to their nature, the possibility of reactivation can not be completely excluded, e.g. in case of a great Ancona landslide, Italy [9]. In case of monitoring for anticipation and warning, the monitoring system must be as automated as possible. Nevertheless, regardless of the significant advances in landslide monitoring technologies, the interpretation of monitoring results, especially in the sense of early warning about possible landslide activation, still remains in the domain of subjective interpretation [10].

\section{Measurement parameters}

Although there is a tendency to anticipate landslide activities in urban areas by using monitoring for anticipation and warning, the reality is such that in most cases the reaction comes only after the sliding body has actually moved, and when the monitoring for investigation purposes must be conducted. As already indicated, landslide monitoring for investigation purposes must be conducted during investigation works, during improvement works, and after the end of landslide improvement works. Main parameters covered by landslide monitoring for investigation purposes are: 
Vertical and horizontal displacements of the sliding body, structures and retaining structures

Measurement of horizontal and vertical displacement of the sliding body enables determination of the direction, depth, and rate of displacement, and also of the landslide displacement value. Among these parameters, displacement rate is the most significant for making decisions about further actions. If the sliding rate decreases, an additional time is gained to decide on improvement method to use but, if the displacement rate increases, then a rapid solution must be made. Monitoring displacement of retaining structures during and after improvement works enables comparison of the designed and actually measured values.

\section{Pore pressures}

The landslide displacement rate is directly influenced by pore pressures. If pore pressures increase (for instance, due to infiltration of rainwater into the sliding body), then the displacement rate also increases, while the decrease of pore pressures results in the decrease of the landslide displacement rate.

\section{Groundwater level}

Determination of groundwater level on landslides is significant for designing improvement measures and for stability analyses.

\section{Forces in anchors of retaining structures}

By measuring forces in anchors of retaining structures, it is possible to compare measured force values with design values, and to analyze their significance for the structure during all typical landslide improvement phases (excavations and prestressing).

\section{Measuring equipment}

When selecting landslide monitoring equipment, it is advisable do select direct methods and equipment whose measurement results directly point to the behaviour of landslide and structures constructed for landslide improvement purposes. Methods and equipment which require interpretation and conduct of analyses can also be applied, but they necessitate too much time for reaction in case of unfavourable occurrences. Displacements are measurement values which dominantly provide answers to questions about the behaviour and condition of the sliding body and retaining structures, and about their interaction. According to Savvaidis [11], methods that are used to determine displacements are remote monitoring, photogrammetric methods, geodetic methods, and geotechnical methods. A greater accuracy of equipment must be ensured when displacements are monitored during and after improvement activities than in case of monitoring during investigation works, because in these stages smaller displacements are expected. Piezometers are devices that are used to define pore pressures at the landslide location. Load cells are used for determining forces in anchors of retaining structures. Some studies [12] also mention geophysical methods as being significant for defining the geological model of landslides, and hence also for determining potential slip surface positions and, in the phase of monitoring, they can also be used for groundwater level monitoring.

\section{Remote observations of displacements}

Advantage of remote methods is their ability to monitor large areas without physical presence of people and equipment in such areas. Remote monitoring methods are often applied for mapping various landslide related factors such as surface morphology, structural and lithological properties, and changes of these factors over time. Unlike optical sensors which enable mapping of mentioned factors, radar measurements linked to satellites [9, 13, 14], or ground-based stations [15, 16], have been used in recent times to monitor displacements. Their development is the result of development of satellite and radar technologies, and has also been spurred by the fact that they can be used in all weather conditions. These methods are used to measure the total quantity of energy that comes back to radar after interaction with the surface of the Earth. Some radar technologies that have proven to be quite effective are the radar recording technology SAR (Synthetic Aperture Radar), radar interferometry InSAR (Interferometric Synthetic Aperture Radar), and especially the differential interferometry DinSAR (Differential Interferometric Synthetic Aperture Radar). SAR technology uses radar to create high resolution images where the magnitude and the phase of the signal received from a number of impulses, are analysed in the signal processing phase. The operating principle of the InSAR technology is based on the use of two antennas positioned vertically and horizontally on the same satellite. One antenna emits the signal, and both antennas receive the return signal, which results in the creation of two images [17]. The most accurate type of interferometric sensing is the differential interferometry DinSAR [18] by which small (millimetric) terrain deformations can be registered between two consecutive measurements, which enables mapping and monitoring displacements of a sliding body. Unlike traditional geodetic methods, the DinSAR method enables determination of displacements of the entire sliding body. The radar system during the data collection process is shown in Figure 1.a.



Figure 1. Remote sensing: a) by radar satellite measurements [18]; b) LIDAR technology [19] 
In recent years, the LIDAR technology (Light Detection and Ranging) has been increasingly used for landslide monitoring. It is an optical-mechanical procedure for the collection of spatial data [19]. The principal advantage of this technology is its full automation and very accurate surveying results [20]. It enables determination, at a very high-resolution, of morphological structures pointing to the presence of landslides, as well as gathering of qualitative and quantitative data aboutchanges in terrain elevation. The method is also very useful and efficient on landslides with vegetation, which may present a problem when other methods are used [21]. The laser scanner is used to determine a three-dimensional position of a point on a landslide. This scanner can be mounted on an airplane or helicopter, but may also be located on the ground surface (Figure 1b).

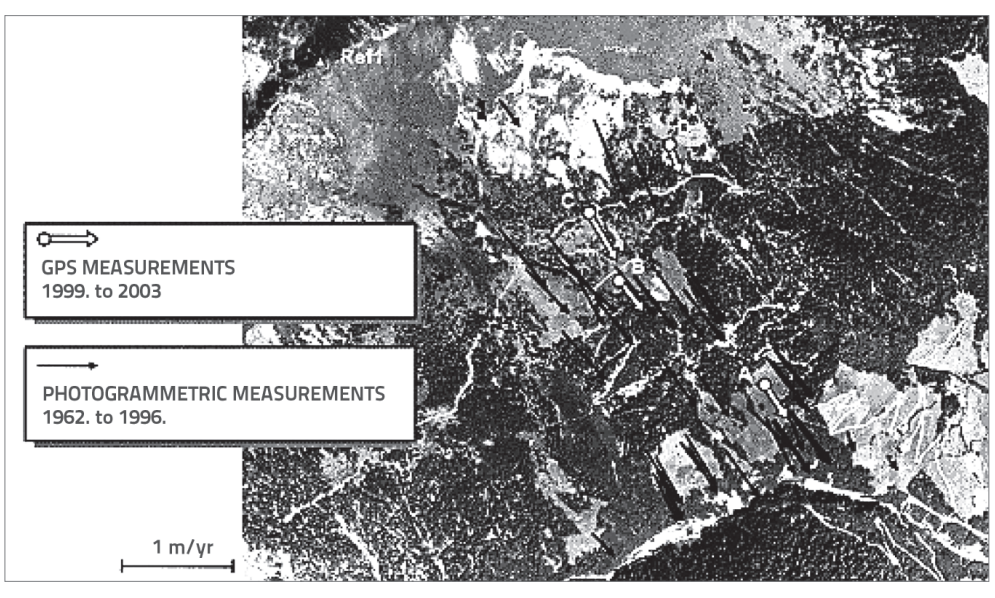

Figure 2. Comparison of displacements obtained by photogrammetric methods and GPS measurements on a landslide example in Austria [22]

\section{Photogrammetric observations of displacements}

Vertical and horizontal displacements can also be determined by remote sensing of displacements using the photogrammetric technique. By comparing the photographs acquired on different dates, it is possible to determine the displacements of selected points on the terrain $[9,22,23]$. Photographs can be obtained using various sensors (still-image cameras, video cameras) linked to satellites, airplanes, and helicopters, and also using sensors located on the ground surface (fixed sensors). The aerial and ground photogrammetry methods are extensively used in landslide displacement determination, as they enable considerable time savings and a practically unlimited number of points that can be considered [24]. Collected data are stored as a structured digital record by means of analytic and digital photogrammetric methods. The precision of photogrammetric methods has increased considerably in recent years, and so the method has become highly attractive for accurate determination of landslide displacements. Landslide displacement comparisons made in Austria [22] between photogrammetric methods (in the period from 1962 to 1996) and GPS measurements (from 1999 to 2003) are shown in Figure 2.

\section{Geodetic observation of displacements}

The geodetic monitoring of landslides, Figure 3, enables determination of vertical and horizontal displacements, and hence definition of the movement orientation and velocity. In all types of geodetic monitoring activities, the values and directions of displacements can be calculated from the difference of coordinates measured during two consecutive measurements. Geodetic monitoring can successfully be conducted only if stabilized points, i.e. geodetic benchmarks, are appropriately positioned on the landslide. Geodetic instruments that can be used for the determination of relative or absolute coordinates of particular points across the landslide are traditional geodetic instruments, and instruments for the determination of coordinates via satellite, GPS (Global Positioning System).

Total stations are currently in use for traditional geodetic measurements of displacement. Their declared accuracy ranges up to $\pm 0.6 \mathrm{~mm}+1 \mathrm{ppm}$ for prism readouts $( \pm 2 \mathrm{~mm}+2 \mathrm{ppm}$ for any surface, vertical angles up to $0.5^{\prime \prime}$ and automatic target recognition up to $1 "$ ). Total measuring stations are actually electronic tachymeters in which angles and lengths are measured electronically. Traditional geodetic observations require a stable base outside of the landslide zone, and at least two such base points are required (three are recommended). In order to achieve a greater accuracy, the system of forced instrument positioning is necessary $[25,26]$, and the highest precision is obtained when instruments are permanently positioned at base points [27]. Measurements are conducted quite rapidly so that for instance determination of three-dimensional coordinates on the surface where 20 prisms are placed can be conducted within 17 minutes [17]. The weakness of these measurements is that an undisturbed (unobstructed) line of vision is needed between the instrument and the prism, and the fact that vertical refraction error reduces accuracy of information about measured heights. High accuracies can nowadays be achieved through the use of GPS for monitoring displacements [22, 28]. Such high accuracies are even further increased by post-processing during which measured values for landslide benchmarks are compared with measurements made at the same period of time on well stabilized points near the landslide. If stationary devices are used over a longer signal reception period, then the following accuracy, with post-processing, can be achieved: horizontal $3 \mathrm{~mm}+0.5 \mathrm{ppm}$, vertical $6 \mathrm{~mm}+0.5 \mathrm{ppm}$ [27].

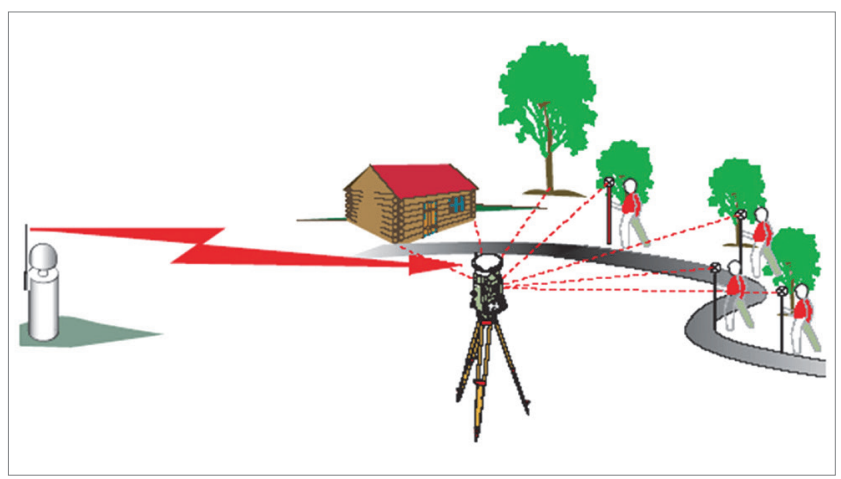

Figure 3. Geodetic observation of displacements 


\section{Geotechnical observation of displacements}

Geotechnical observations of displacements include the use of inclinometers, extensometers, sliding deformeters and micrometers, crack-meters, chain deflectometers, optical fibres and clinometers.

On landslides, inclinometers are used to measure change of inclination of vertical cased boreholes or pipes installed in retaining structures (piles, diaphragms). This enables determination of the sliding depth and displacement direction, and calculation of displacements and displacement rates between individual measurements. Present-day inclinometers can be divided into two types: probe inclinometers and in-place inclinometers. In case of probe inclinometers, pipes (casing) with grooves are installed into boreholes. The inclinometer probe with wheels that are inserted into the grooves is descended and the inclination between two measurement points is measured at specified intervals where wheels are stopped. The probe is equipped with sensors for measuring inclination in one or two perpendicular planes, which coincide with directions that are defined by the opposing grooves. Pipe inclination measurements are compared to one another and thus the change in inclination and displacement is calculated. The probe inclinometer accuracy that can be achieved for in-situ conditions, is up to $\pm 0.1 \mathrm{~mm} / \mathrm{m}$. The measurement principle of probe inclinometer is presented in Figure 4.

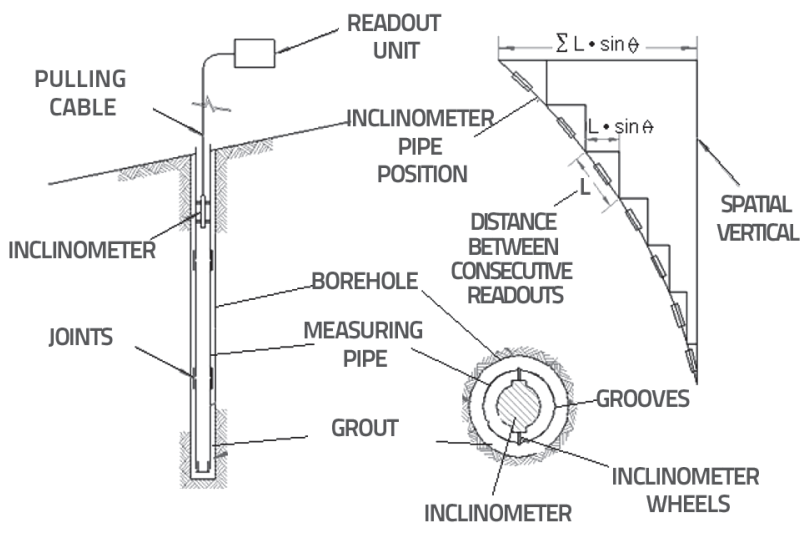

Figure 4. Inclinometer measurement principle [29]

In case of in-place inclinometers, the casing is equipped with sensors that are installed at depths where sliding is expected to occur. The readouts can be made either at specified time intervals or continuously. Readout values are sent to a data acquisition and analysis system. In-place inclinometers are more suitable in situations when the depth of sliding is relatively well known or narrowed down to a particular zone, as a wider measuring zone requires more sensors and increases the costs.

The general name extensometer (Figure 5) refers to various devices that are used to measure the change in length between two or more points. They can be placed in boreholes or on the ground surface where they are positioned either locally or globally. In the first case, extensometers of various lengths are anchored at different depths along the borehole, and by measuring the change in distance from the ground surface to the points at selected depths, the sliding depth and displacement value can be determined. Instead of using several extensometers of different lengths, extensometers with sensors placed at uniform intervals can be used. They provide data about the change within each interval [30]. In case of local positioning on the ground surface, extensometers are installed over cracks in the terrain or on structures. Consecutive readouts show whether the cracks are widening, i.e. whether the landslide is active and whether its activity has any effects on man-made structures. In case of global positioning on the ground surface, extensometers are placed along the landslide [31], usually in the direction of expected displacements, and the change of distance between a fixed point outside of the landslide, and one or several points within the landslide, is measured. The above mentioned extensometers are in-place extensometers but, just like in case of inclinometers, probe extensometers are also available.

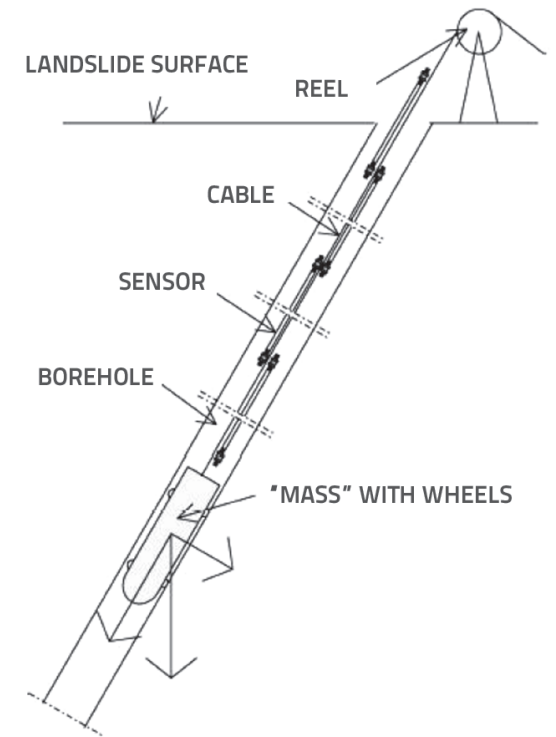

Figure 5. Extensometer measurement principle [29]

The sliding deformeter and sliding micrometer, which represent probe extensometers, enable continuous measurement of deformations along installed pipes. Pipes can be installed in boreholes or in structures (piles, diaphragms, etc.). The sliding deformeter and sliding micrometer accuracy that can be achieved for in-situ conditions is up to $\pm 0.03 \mathrm{~mm} / \mathrm{m}$ and $\pm 0.003 \mathrm{~mm} / \mathrm{m}$, respectively. Deformation measurements by sliding deformeter are based on measurement of relative deformations of installed pipes connected by telescopic joints, as shown in Figure 6. The deformeter is inserted into the measuring pipe and can be moved between the joints. When reaching joints, the deformeter turns by $45^{\circ}$, and when the deformeter is pulled, the sensor measuring the distance between joints is activated. The same procedure is repeated for each pair of joints. Repeated measurements of the distance between joints result in relative deformations of the measuring pipe (per $\left.\mathrm{m}^{\prime}\right)$, and soil displacements are calculated by integration of these data. 


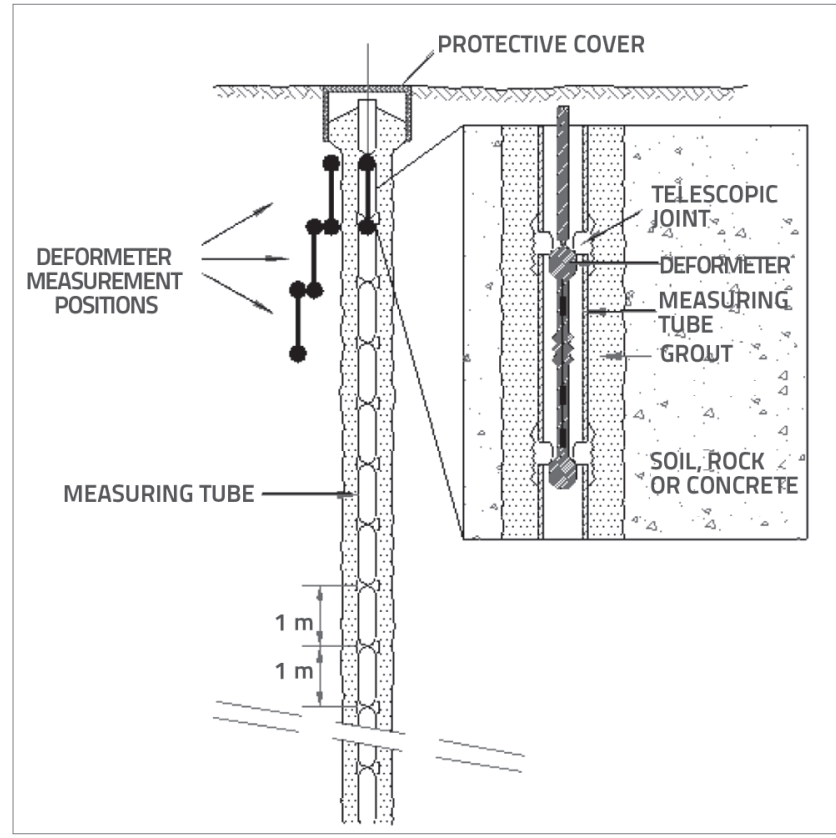

Figure 6. Sliding deformeter measurement principle [7]

Crack-meters are simple instruments that can be quite useful for early detection of displacement of sliding bodies. They are based on the measurement of displacement between two points that have started to separate [11]. The chain deflectometer, Figure 7, is used to monitor deformations below the ground surface, and is installed in fixed pipes connected with soil by grout. The deflectometer is composed of several interconnected rods which have, at their ends, electronic heads which measure deflection between two rods in the $x$ and $y$ direction.

Optical fibres can be efficiently used to measure deformations in soil [33, 34]. These fibres can be installed along the entire area of the landslide, and hence continuous data can be obtained for each point along the landslide. Other than on the surface, optical fibres can also be installed along the depth.

The clinometer (tiltmeter) measurement, Figure 8 , is based on the measurement of rotation angle of special supports that are installed in the structure using a special drilling and grouting procedure. The difference between two measurement results is a rotation of the support expressed in $\mathrm{mm} / \mathrm{m}$.

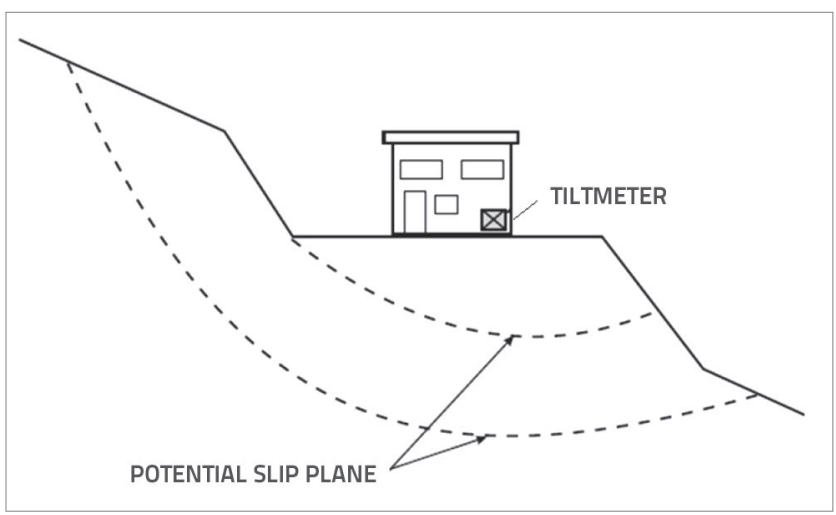

Figure 8. Installation of clinometer (tiltmeter) in a structure located on a landslide [35]

\section{Pore pressure measurement}

Pore pressures are measured by installing piezometers having the zone of reach at precisely defined depths. Ideally, the zone of reach should be concentrated at depths where permeability changes significantly, and in the zone where sliding may be expected. The simplest and most reliable devices are Casagrande piezometers, Figure 9a. Casagrande piezometer for pore pressure measurements consists of the filter top connected to a pipe. The filter is made of polyethylene or porous stone, while the pipe is usually made of PVC (except in soft soil where steel pipes are used). Once pipes with filter top are installed into the borehole, the area around the filter top is covered with sand. The top of the filter zone is sealed with bentonite. Water levels in piezometers are registered in intervals defined in advance or as necessary (after significant precipitation, snow melting, etc.). Twin-tube piezometers, pneumatic piezometers, vibratingwire piezometers, and electrical-resistance piezometers, are also in use. When pressures need to be measured at different depths, double or triple Casagrande piezometers [36] and multiple electrical piezometers [27] can be installed in a single borehole, instead of installing individual piezometers in several boreholes. Casagrande pipe piezometers can also be used for approximate determination of sliding depth. This can be done by measuring the depth of passability by inserting a steel rod. If piezometers are installed at a sufficient depth, the installed pipes may become impassable at the sliding depth due to landslide activity.

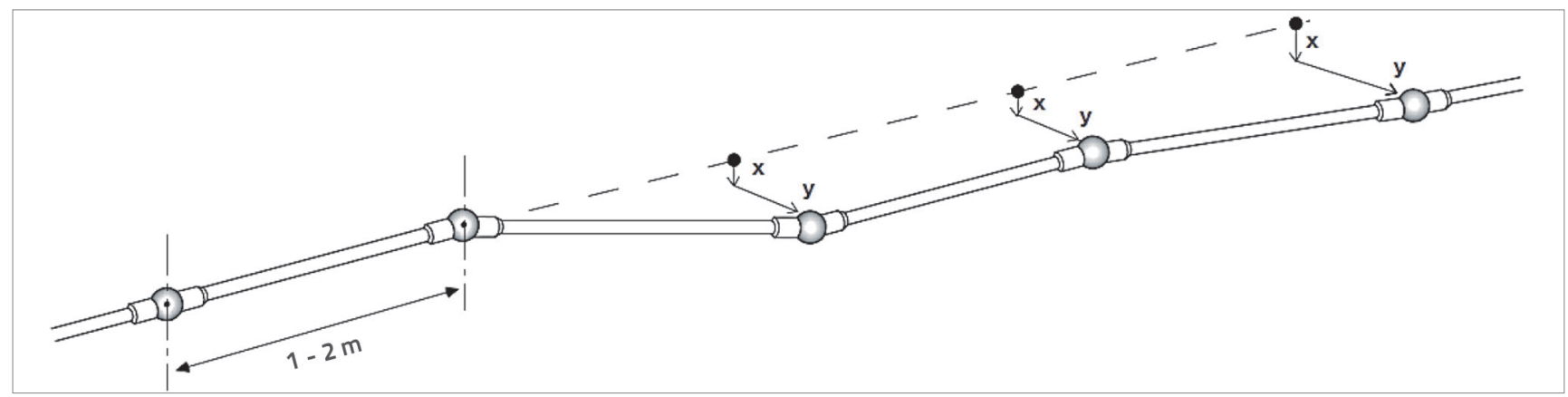

Figure 7. Chain deflectometer measurement principle [32] 
a)

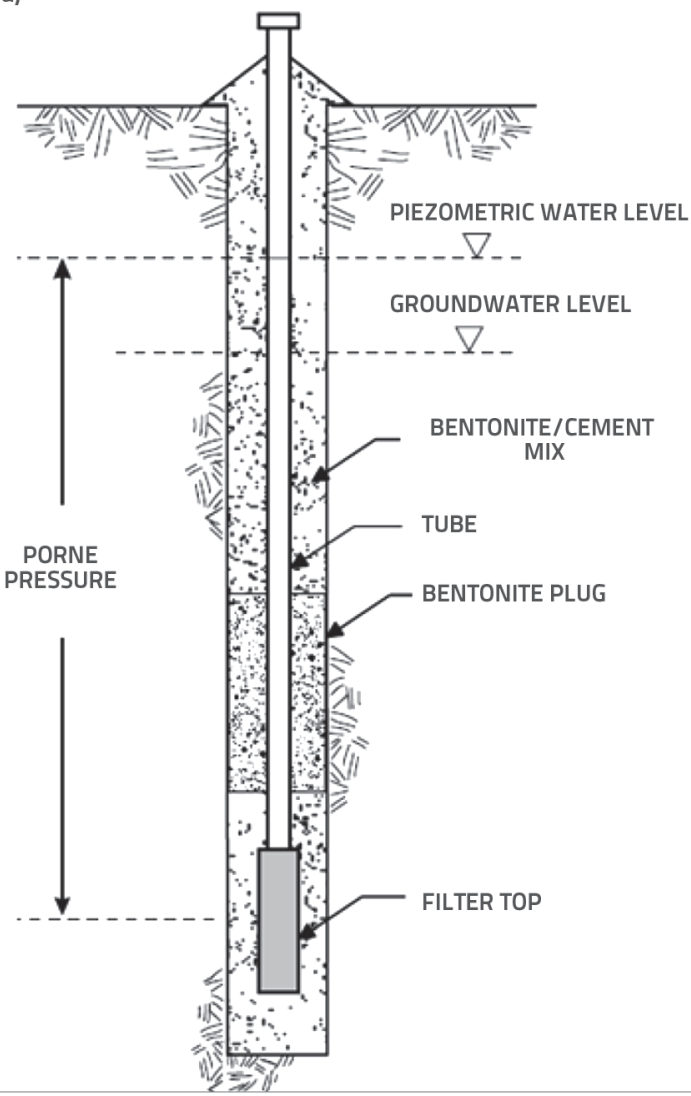

b)

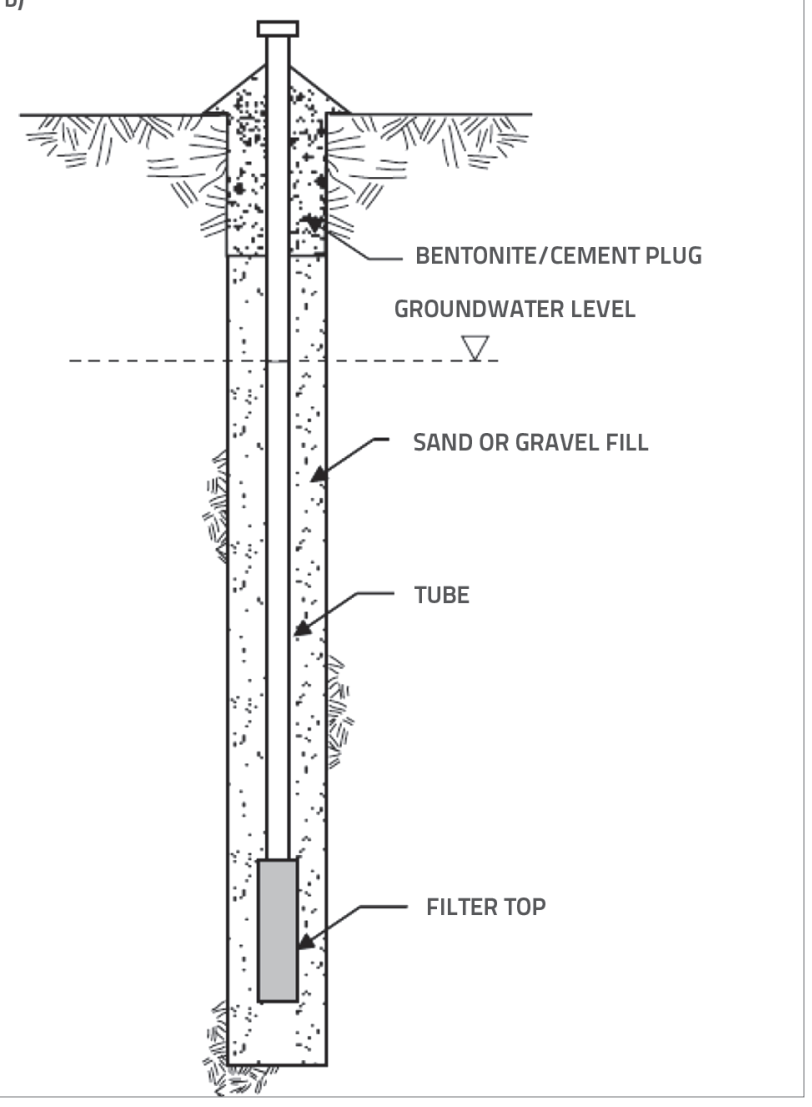

Figure 9. Pore water pressure measurement: a) using Casagrande piezometer; b) groundwater level measurement, [35]

\section{Groundwater level measurement in soil}

Groundwater level measurements are conducted either in uncased boreholes, or perforated pipes are installed into boreholes so that they receive water along the entire depth of the borehole. The monitoring well, Figure 9.b, is used for ground water level monitoring. The well also makes use of the filter top but, unlike the Casagrande piezometer, it does not have a bentonite plug, and the space between the pipe and borehole wall is filled with sand or gravel. As filter top is not protected from vertical water inflow, this setup enables determination of groundwater levels, but cannot be used to determine pore pressures in soil. Geophysical methods can also be used to determine the groundwater level in soil, and zones of higher soil moisture. Geoelectrical methods are dominantly used for this purpose.

\section{Force measurement in anchors}

Load cells are installed on anchor head in order to determine forces in anchors. These cells are made of the steel cylinder that is equipped with deformeters. Steel cylinder deformations are converted into electrical signals which are then calibrated, and the force in anchor is obtained as the output data.

\section{Measurement results}

The step that follows after data collection concerns interpretation of measurement results. Inclinometer and deformeter (micrometer) measurements provide results in form of displacement - depth diagram, in a certain period of time. Measurement results are most frequently represented in terms of the measured value - time diagram. For instance, if displacement of one point along the landslide is measured, the result is presented in form of the displacement - time diagram. This point can be a geodetic benchmark, top of inclinometer, deformeter (micrometer)... During the interpretation of displacement measurement results, two questions of significance to the "course" of interpretation arise. These questions are:

1. Can the same in-situ measurement results be obtained two times in a row (no displacement)?

2. Can the measurement error be recognised and corrected (by not accepting the measurement result as a measured displacement)?

In order to answer the first question, a proper explanation of the terms measurement accuracy and measurement precision must be given. The measurement accuracy is the level of correspondence of individual or average measurement results 
with the real measurement value or an accepted reference value. The measurement precision is the level of correspondence between individual measurements made under specified conditions. Precision is synonymous to repeatability. The scheme explaining the accuracy and precision, presented by Dunnicliff [29], is shown in Figure 10.
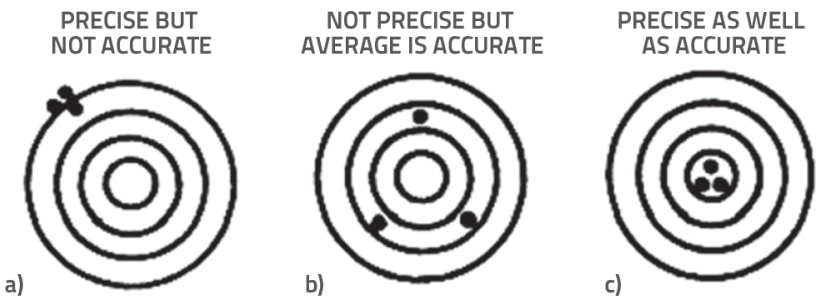

Figure 10. Scheme of accuracy and precision according to Dunncliff [29]

The answer to the first question is exclusively dependent on precision. For instance, if the $5 \mathrm{~mm}$ displacement is measured in two consecutive measurements, then it can be said that the measurement is precise. However this does not say anything about accuracy of the measured displacement that may, but also may not, amount to $5 \mathrm{~mm}$. Consecutive measurements can result in the same measurement results, and these consecutive measurement results indicate that no displacement occurred in between the measurements. To determine accuracy of a measurement value, we have to answer the second question which is related to the course of interpretation.

The accuracy of measurements depends on a number of measurement system factors including the mode in which the measuring equipment is installed, properties of the measuring equipment, experience and training of persons that perform the measurements, procedure and conduct of measurements, and the way in which results are treated, presented and interpreted. A mathematical equivalent to accuracy is error. It is the deviation between measured and real values. Mikkelsen [37] explains measurement errors on an example of inclinometer measurements, and this example is a good indicator for measurement errors made using other measuring devices. According to Mikkelsen, the total measurement error is the sum of the accidental error and systematic error, where the influence of the accidental error on the total error is much smaller when compared to the influence of systematic error. However, while accidental errors can only be minimized, systematic errors may be corrected using appropriate mathematical procedures. Factors that mostly influence the systematic error during inclinometer measurements are errors due to deviation from the vertical (bias-shift), rotation error, and depth positioning error. The extent to which the measurement error can influence the final results has been shown by Mikkelsen on the example of the bias-shift error during inclinometer measurement at a sea cliff site [37]. Although it was expected that horizontal displacement of the cliff will be oriented toward the sea, inclinometer measurement results have pointed to the negative displacement (toward the mainland) of $20 \mathrm{~mm}$ (Figure 11a). Corrected results "have revealed" that displacements are in fact positive (toward the sea) and that they amount to $5 \mathrm{~mm}$ (Figure 11c.).

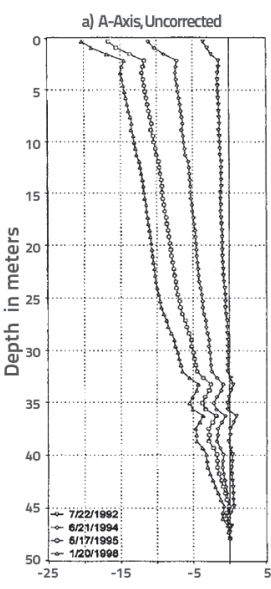

Cum. Displacement [mm]10/17/1991

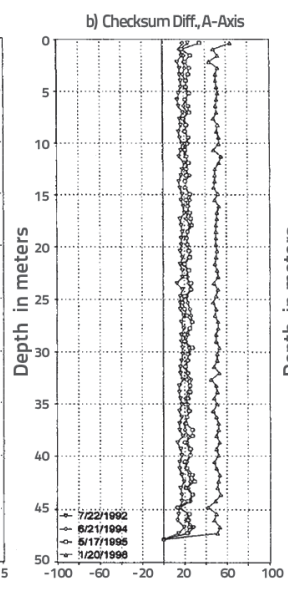

Dif. checksum [rdg. unit]

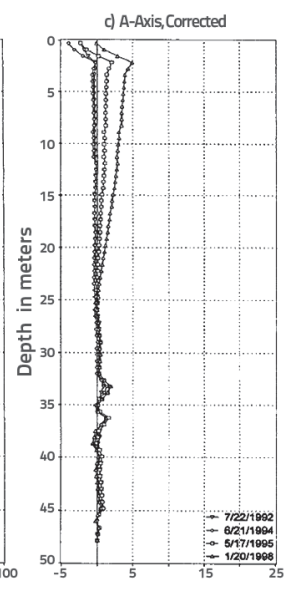

Cum. Displacement [mm]10/17/1991
Figure 11. Correction of inclinometer error due to bias-shift [37]

Mikkelsen indicates that even the depth positioning error, which is hardest to correct, has to be at least identified and, if possible, corrected in order to avoid inaccurate measurement results. It can therefore be concluded that it is possible to identify and correct a measurement error and to refuse to accept the measurement result as measured displacement. At that, the knowledge and experience of the result interpreter is of crucial significance.

\section{Monitoring of Grmoščica Landslide in Zagreb}

Grmoščica Landslide in Zagreb is a well documented example of landslide monitoring in an urban environment. The old Grmoščica landslide in Zagreb, Figure 12, was reactivated in 1993 due to unfavourable hydrological conditions, as a result of urbanisation of the area, without proper resolution of the drainage issue. With the landslide area of about 2 ha, and the sliding depth from 5 to 9 $\mathrm{m}$, the total of about $15 \times 10^{4} \mathrm{~m}^{3}$ of soil was in movement.

After reactivation, the landslide was active for more than 10 years before improvement works were undertaken. In the period after the reactivation, geotechnical investigations were carried out in two parts. In the scope of the first part of geotechnical investigations the monitoring was conducted in 1993, while it was conducted from 1998 to 2000 in the scope of the second part of geotechnical investigations. In the scope of the first part, piezometers were installed into boreholes, while the second part of the monitoring included installation of inclinometers and geodetic benchmarks, and additional piezometers. The situation on the landslide was monitored until 2003.

The design for the first phase of landslide improvement was completed in 2002 [38], and the works in the scope of the first improvement phase were conducted from 2005 to 2007. Geodetic benchmarks, inclinometers, and load cells were installed on retaining structures during the improvement works 
in order to control their behaviour, i.e. to check whether their behaviour corresponds to design predictions. At the same time, monitoring activities were conducted to control the situation on the landslide. The monitoring after remedial work was conducted from October 2007 to November 2009. During this monitoring, it was concluded that the improvement works (i.e. their first phase) were conducted successfully [39]. The disposition of measuring equipment during investigations is presented in Figure 13.

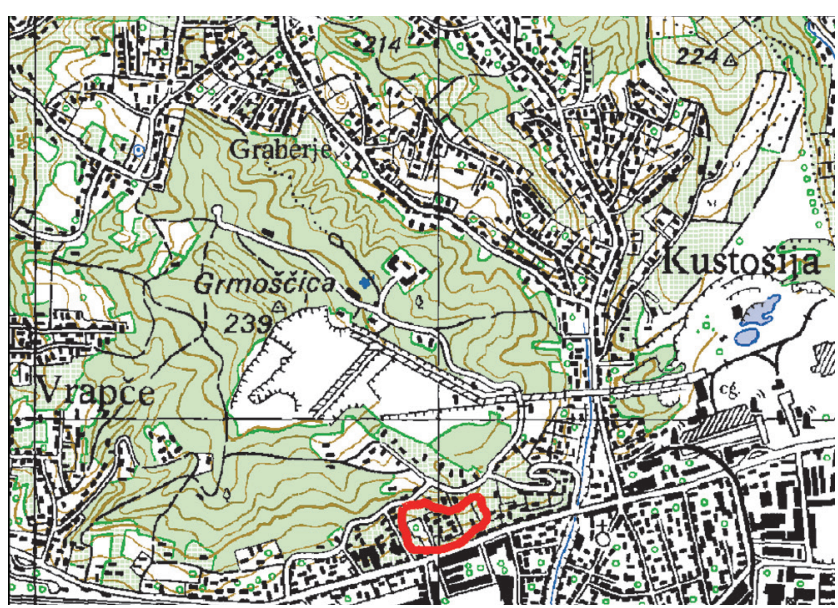

Figure 12. Position of the Grmoščica landslide on the map originally scaled at 1:25,000

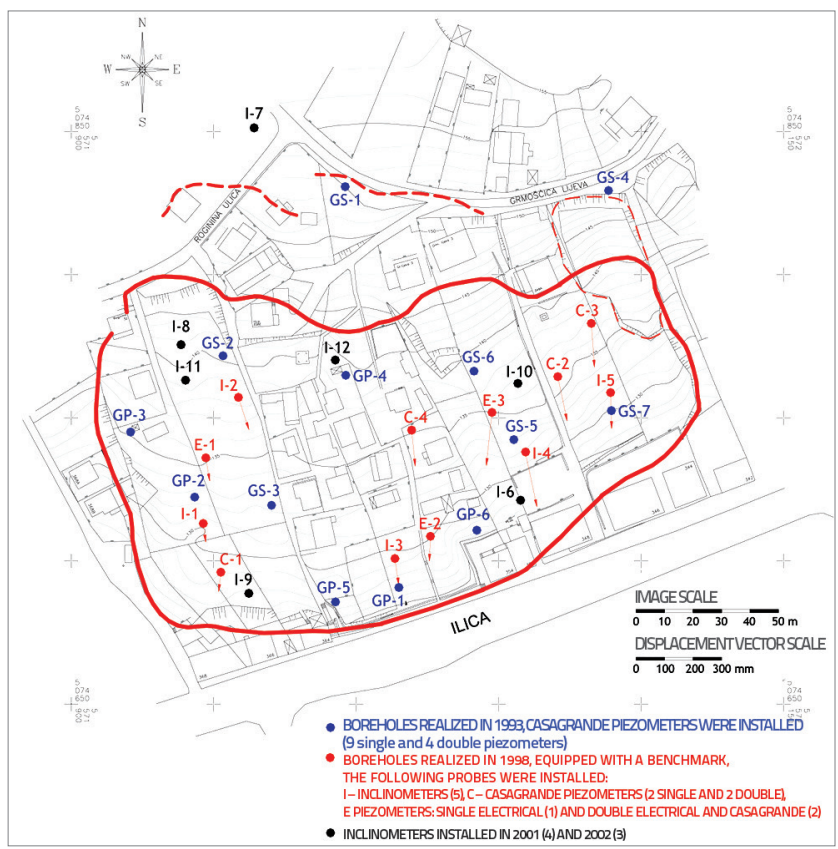

Figure 13. Grmoščica landslide, measuring equipment installed during geotechnical investigations

The Grmoščica landslide was improved by means of retaining structures (anchored pile walls), and bored drains were installed as an additional protective measure. Each retaining structure was made of one row of piles $120 \mathrm{~cm}$ in diameter, spaced at 1.50 $\mathrm{m}$ intervals (axis-to-axis), connected with the $1.50 \times 1.50 \mathrm{~m}$ head beam. The total height of retaining structures amounts to $16.00 \mathrm{~m}$ and the pile bottom had to be at least $8 \mathrm{~m}$ below the sliding surface. Anchors inclined at $25^{\circ}$ were spaced at $1.50 \mathrm{~m}$ intervals. Three rows of anchors were installed at position 1.1, while two rows were installed at the remaining retaining structures. Top anchors are 28.0 $\mathrm{m}$ in total length (free anchor length: $20.0 \mathrm{~m}$, fixed anchor length: 8.0 $\mathrm{m})$. The second row of anchors measures $23.0 \mathrm{~m}$ in total length (15.0 $+8.0)$. The third row of anchors at position 1.1 measures $18.0 \mathrm{~m}$ in total length $(10.0+8.0)$. The anchors were prestressed by the force of $100 \mathrm{kN}$. Bored drains were installed through the spaces between the piles. Long bored drains were installed (42-75 $\mathrm{m}$ in length) as well as short ones ( $9 \mathrm{~m}$ in length). Typical cross-section of the adopted structure is shown in Figure 14.

The disposition of measuring equipment during and after landslide improvement, with positions of retaining structures, is shown in Figure 15.



Figure 14. Typical cross section of the retaining structure [38]

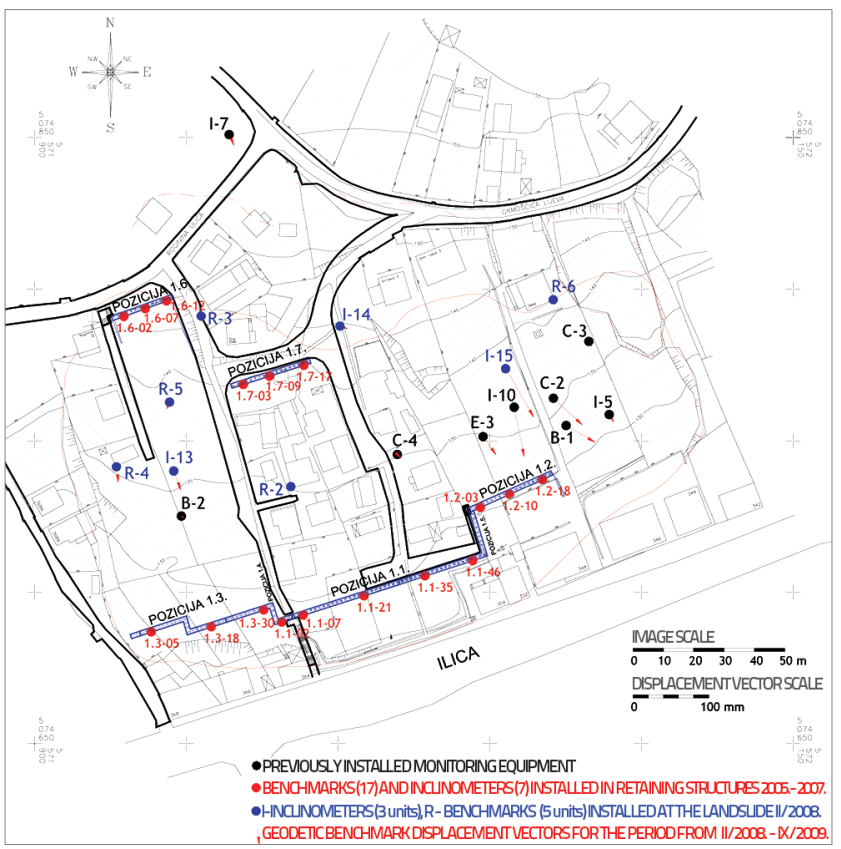

Figure 15. Grmoščica landslide, measuring equipment installed during and after the improvement works

\subsection{Piezometric measurements}

Piezometric measurements were conducted at Grmoščica landslide in order to determine pore pressures at the slip plane level. Measurements were made in the first part and in the second part of geotechnical investigations. In the first part of geotechnical 
investigations, single and double Casagrande piezometers were installed in all boreholes, i.e. the total of 9 single and 4 double piezometers were installed (Figure 13). The second part of geotechnical investigations comprised installation of 7 piezometers, out of which 2 single and 2 double Casagrande piezometers, 1 electrical piezometer and 2 double piezometers as a combination of electrical and Casagrande piezometers (Figure 13), while piezometers installed in the first part of geotechnical investigations were included in the monitoring. According to data collected in the first part of geotechnical investigations, Ortolan [40] interpreted contour lines of maximum expected piezometric pressures at the slip plane level for the entire landslide area that were relevant for stability analyses. Corrections of piezometric pressures were made according to piezometer measurement results that were obtained in the second part of geotechnical investigations. Results of piezometric measurements conducted in the second part of geotechnical investigations are presented in Figure 16 in form of the absolute water level - time diagram, for piezometers with the zone of reach approximately at the slip plane level.

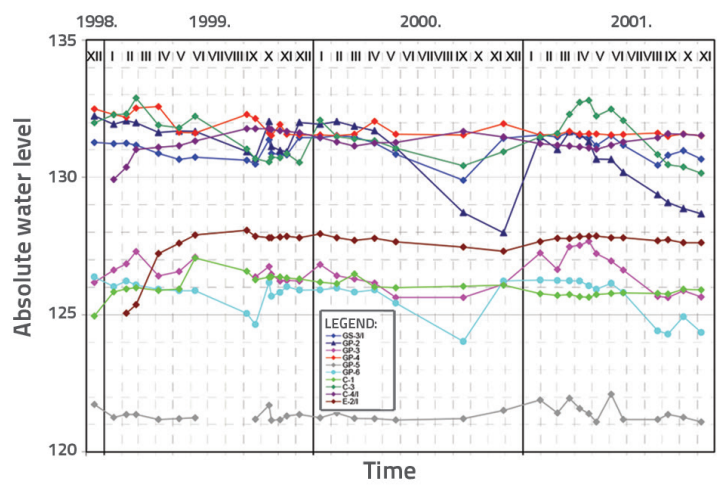

Figure 16. Results of piezometric measurements made during the second part of geotechnical investigations for piezometers with the zone of reach approximately at the slip plane level [3]

In the course of these measurements, the piezometer passability was checked by inserting a rod $1 \mathrm{~m}$ in length. Although signs of displacement were registered at the landslide during the first part of geotechnical investigations, and this in the sense of widening of old cracks and occurrence of new ones, all piezometers have remained fully passable until the end of measurements. In the second part of geotechnical investigations, it was established that some piezometers are not passable, which provided valuable information about the sliding depth. Piezometer monitoring was to be continued even after the improvement, but only a smaller number of piezometers were preserved until the end of landslide improvement activities, and most of them became impassable.

\subsection{Geodetic monitoring}

Geodetic observations at the Grmoščica landslide were conducted in order to identify horizontal and vertical displacements of the sliding body and retaining structures. Geodetic observations of displacement of the sliding body started in the second part of geotechnical investigations when geodetic benchmarks were installed on the top of concrete foundations of piezometers and inclinometers (Figure 13). The observations continued during the construction of retaining structures and after completion of the landslide improvement activities. During the improvement works, benchmarks were installed at the retaining structures as well (Figure 15).

GPS measurements were made in the period from 1998 to 2002. The reason behind selection of GPS measurements were difficulties in the establishment of a stable basis for measurements. GPS measurements were made using receivers of declared accuracy: horizontal $\pm 5 \mathrm{~mm}+1 \mathrm{ppm}$, and vertical $\pm 10 \mathrm{~mm}+1 \mathrm{ppm}$, for the 1 $\mathrm{km}$ vector measurement, during 20 minutes, with signal reception from 5 satellites. In 2002 the switch was made to terrestrial measurements with the total measuring station. The reason for switching to terrestrial measurements were problems with GPS measurements due to disturbances caused by vegetation and weather conditions during some measurements. Average displacement rates registered at individual benchmarks in the second part of geotechnical investigations amounted to 20-60 $\mathrm{mm}$ /year. It was concluded from geodetic observation results that the landslide does not behave as a uniform sliding body, because displacement rates differed at individual locations. Largest displacements were registered at the east part of landslide, and the smallest ones at the west side.

Monitoring of the sliding body during the improvement revealed that the improvement works did not significantly influence movement of the sliding body, as during these works displacements occurred at approximately the same rate as prior to improvement. The sliding body monitoring conducted after improvement proved that displacement velocities have been reduced significantly. Thus displacement rates after improvement amounted to $12-15 \mathrm{~mm}$ /year at the west part of the landslide, while displacements amounted to $13-40 \mathrm{~mm}$ /year in the east part that has not been fully improved. It was estimated that measurements of benchmarks installed on the landslide were accurate to $\pm 5 \mathrm{~mm}$ in the horizontal and vertical directions. Results of geodetic observations, related to displacements registered at the east part of the landslide after improvement, are presented in form of the displacement - time diagram in Figure 17.

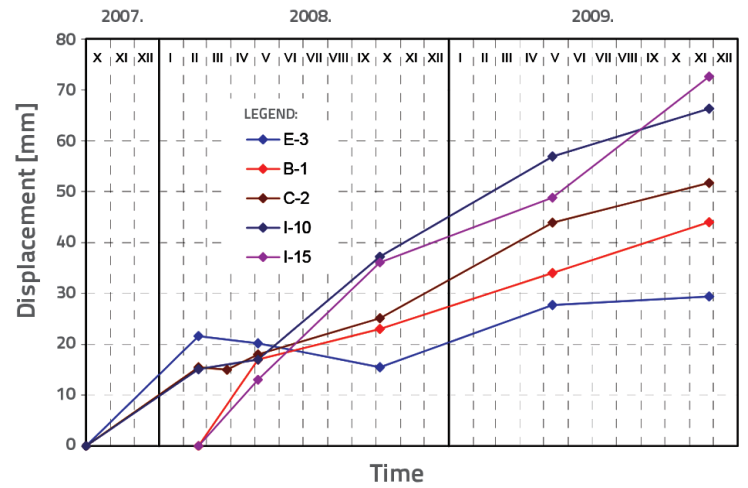

Figure 17. Geodetic results for displacement in the east part of landslide after improvement [3] 
Geodetic monitoring on retaining structures was conducted during and after improvement on 17 benchmarks (Figure 15). The measurement accuracy for benchmarks installed at retaining structures was estimated at $\pm 2 \mathrm{~mm}$ in the northsouth direction and vertically, and at $\pm 5 \mathrm{~mm}$ for the eastwest direction. The displacement measuring accuracy was estimated on the basis of analysis of results and by discarding "impossible" displacements: along retaining structures, contrary to the sliding direction, and benchmark lifting. Values presented are maximums of calculated counterdisplacements between two consecutive measurements.

\subsection{Inclinometer measurements}

Inclinometer measurements were conducted at the Grmoščica landslide in order to determine horizontal displacements of the sliding body and retaining structures, and to determine sliding depths. The accuracy of consecutive inclinometer measurements of horizontal displacement was estimated at $\pm 2 \mathrm{~mm}$ for inclinometers on the landslide, and at $\pm 1 \mathrm{~mm}$ for inclinometers in retaining structures. The accuracy of horizontal displacement measurements by inclinometers was estimated in the same way as for benchmarks.

First inclinometers were placed in the second part of geotechnical investigations when 12 inclinometers were installed on several occasions (Figure 13). In fact, some inclinometers became impassable due to landslide displacements and were therefore replaced by new ones. Measurements in inclinometers I-10 and $\mathrm{I}-12$ are shown in Figure 18. The sliding depth can clearly be seen in both inclinometers.

Inclinometer measurements have shown that the landslide does not behave as a single sliding body, which corresponds to the information obtained through geodetic observations. Maximum displacements registered in inclinometers were obtained at the east part of the landslide, which corresponds to geodetic observation results. An average displacement rate amounted to 28-109 mm/year. During improvement works, inclinometers were installed into piles of retaining structures and, after completion of improvement, they were also installed along the surface of the landslide (Figure 15). According to inclinometer monitoring results, some displacements have been registered even after the improvement activities. Greatest displacements amounting to $36 \mathrm{~mm}$ /year were registered in the inclinometer at the east part of the landslide where no improvement was made. In the west part of the landslide, displacements measured in inclinometer amounted to $9 \mathrm{~mm} /$ year, while they amounted to $4.6 \mathrm{~mm} /$ year in the central part, which is much less compared to the situation prior to improvement.
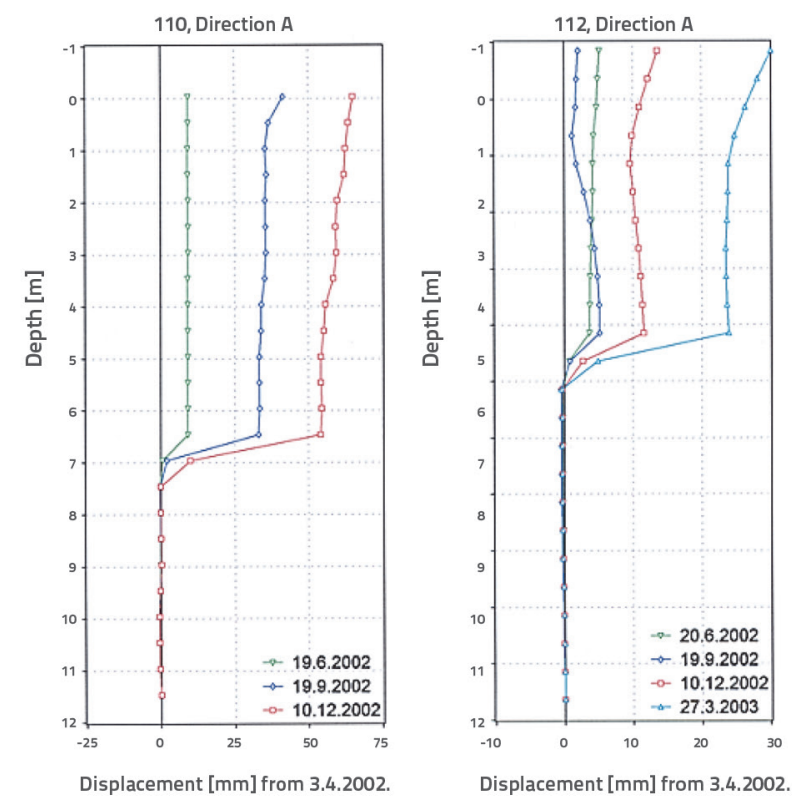

Displacement [mm] from 3.4.2002.

Figure 18. Measurements along the depth at inclinometers I-10 and I-12 [3]

Figure 19 shows displacements over time, as measured in inclinometers installed in the retaining structure 1.1 from the beginning of construction and measurement, and until the end of the monitoring (numbers 7, 21 and 35 correspond to ordinal numbers of piles into which they were installed, Figure 15). The retaining structure 1.1, Figure 15, is the most interesting one as it provides the highest altitude difference, contains 3 rows of anchors (other

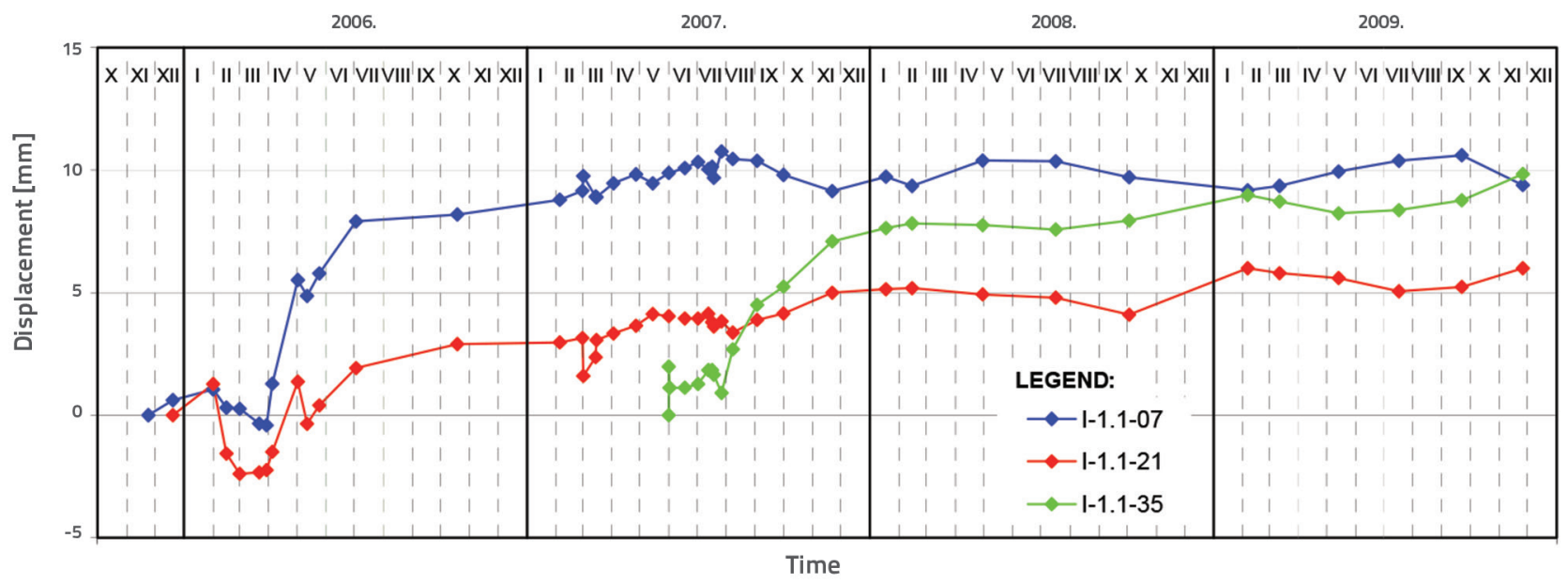

Figure 19. Displacements over time measured in inclinometers installed in the retaining structure 1.1 [3] 


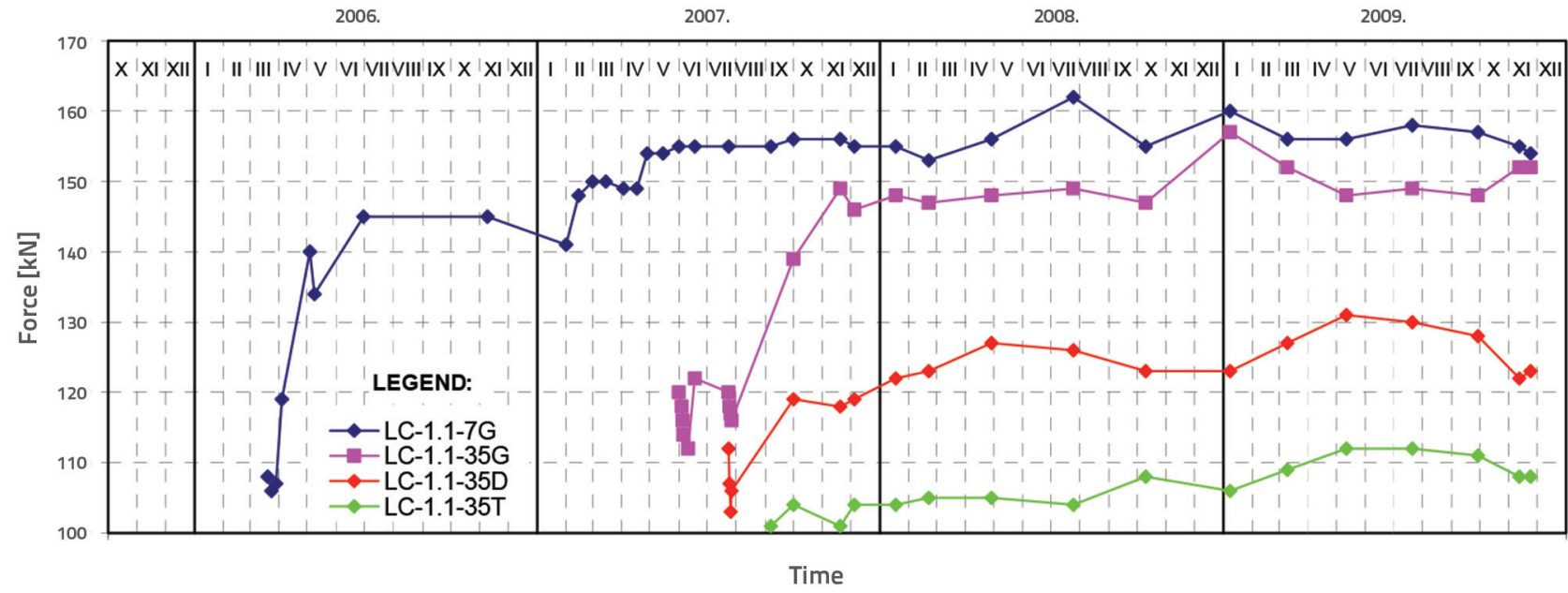

Figure 20. Forces over time, measured in load cells located in anchors of the retaining structure 1.1 [3]

structures have 2 rows each), and was constructed in segments. Figure 19 shows that displacements measured in inclinometers from October 2007 (end of improvement works) and until the end of measurements, are within the preset accuracy range (except for 1-1.1-35 installed in the last completed part of the structure September 2007, which had been showing displacements for some time after installation, but no displacements were registered from the end of 2008 to the end of 2009).

\subsection{Force measurements in anchors of retaining structures}

Forces were measured in anchors of retaining structures by means of load cells installed on anchor heads. The accuracy of force results obtained at load cells amounted to $\pm 1 \mathrm{kN}$, which is the smallest value digitally displayed on the measuring device.

Figure 20 shows changes in forces measured in load cells installed in the retaining structure 1.1 from the time of installation to the end of the monitoring (numbers 7 and 35 correspond to the ordinal numbers of piles into which they were installed, Figure 15, while letters $G, D$ and $T$ denote the top, second and third row of anchors, respectively). It can be seen that changes in force value after construction are much smaller compared to the changes due to construction work (excavations, prestressing of neighbouring anchors in the same or another row).

Comparison of figures 19 and 20 reveals that there are no tendencies of increase in the displacement and force values in the period after improvement. The monitoring conducted has provided appropriate answers with respect to the initially set tasks, which include evaluation of success of activities conducted in the first phase of improvement works, definition of the need to conduct additional improvement activities, and definition of possibilities for further construction within the landslide zone.

\section{Conclusion}

In order to identify, and then remove or mitigate, potential risks during monitoring of landslides in urban areas, it is of crucial significance to define the measurement purpose, measurement parameters, measuring equipment, and measurement results. On landslide locations, monitoring is conducted in order to investigate, in case when the landslide is already activated, or in order to anticipate and warn, when there are indications that a new landslide could be activated. Monitoring for investigation purposes generally implies monitoring during preliminary geotechnical investigations, during landslide improvement activities, and after landslide improvement. Measurement parameters covered by monitoring are vertical and horizontal displacements of the sliding body and of retaining structures that are built to improve the landslide. Displacements are determined by remote observations, geodetic observations, and geotechnical observations (inclinometers, extensometers, deformeters, micrometers, crack-meters, chain deflectometers, optic fibres, clinometers). Other parameters significant for understanding behaviour of landslides include pore pressures (piezometers), ground water level (observation wells and geophysical methods), and forces in anchors of retaining structures (load cells). The choice of measuring equipment must be adapted to the purpose of measurement, measurement parameters, and expected results. Measurement results are influenced by precision and accuracy, i.e. error as the mathematical equivalent to accuracy. The experience and knowledge of result interpreters is of crucial significance in the result interpretation process, because they have to identify and correct any potential errors. The Grmoščica landslide in Zagreb is an example of a well documented landslide in an urban area. Landslide behaviour was monitored in two monitoring parts during preliminary geotechnical investigations, and through monitoring during and after landslide improvement. During preliminary geotechnical investigations, the information was gathered about landslide properties which enabled creation of a solid basis for the improvement design. Monitoring during the improvement works revealed that the construction of retaining structures did not influence the landslide displacement rate, while the landslide monitoring after the improvement works showed that the first phase of improvement activities has been successful. 


\section{REFERENCES}

[1] Morgenstern, N.R., Martin, C.D.: Landslides: Seeing the Ground, Keynote lecture, Proc. of the 10th International Symposium on Landslides and Engineered Slopes. Xi'an, pp. 3-23, 2008.

[2] Morgenstern, N.R.: Performance in Geotechnical Practice: Inaugural Lumb Lecture, Transactions Hong Kong Institute of Engineers , 7 (2), pp. 1-15, 2000.

[3] Mihalinec, Z.: Monitoring klizišta u urbanim sredinama, Magistarski rad, Gradevinski fakultet Sveučilišta u Zagrebu, Zagreb, 2011.

[4] Moore, D.P., Imrie, A.S., Baker, D.G.: Rockslide Risk Reduction Using Monitoring, Proc. Can. Dam Safety Assn. Annual Meeting, Whistler, 1991.

[5] Kovačević, M.S.: The Observational Method and the Use of Geotechnical Measurements, Proc. of the 13th ECSMGE, Prag, pp. 575-582, 2003.

[6] Kovačević, M.S., Szavits-Nossan, V.: Interactive Design - Croatian Experience, 13th Danube-European Conference on Geotechnical Engineering, Ljubljana, pp. 451-455, 2006.

[7] Kovačević, M.S., Arapov, I., Lušo, P., Kuželički, R.: Povratne numeričke analize u tunelu Pećine, 4. Savjetovanje HGD-a Ojačanje tla i stijena, Opatija, pp. 143-152, 2006.

[8] Mihalinec, Z., Škevin, J., Kovačević, M.S.: Calculated and Measured Horizontal Deformations of High Reinforced Embankment, Proc. of the 11th International Conference of IACMAG, Torino, pp. 349355, 2005.

[9] Cotecchia,V.: Experience Drawn from the Great Ancona Landslide of 1982., The Second Hans Cloos Lecture, Bulletin of Eng. Geology and the Environment, 65 (1), pp. 1-41, 2006.

[10] Eberhardt, E., Watson, A.D., Loew, S.: Improving the Interpretation of Slope Monitoring and Early Warning Data Through Better Understanding of Complex Deep-seated Landslide Failure Mechanisms, Proc. of the 10th International Symposium on Landslides and Engineered Slopes, Xi'an (China), Vol.1, Taylor \& Francis Group, pp. 39-51, 2008.

[11] Savvaidis, P.D.: Existing Landslide Monitoring Systems and Technique, From Stars to Earth and Culture, pp. 242-258, 2003.

[12] The ClimChAlp partnership: Slope Monitoring Methods - A State of the Art Report, Climate Change, Impacts and Adaptation Strategies in the Alpine Space (ClimChAlp), Work Package 6, 179 p., Munich, 2008.

[13] Calcaterra, D., Ramondini, M., Calò, F., Longobardi, V., Parise, M., Galzerano, C.M.: DInSAR Techniques for Monitoring Slowmoving Landslides, Proc. of the 10th International Symposium on Landslides and Engineered Slopes, Xi'an, pp. 1095-1101, 2008.

[14] Cascini, L., Peduto, D., Fornaro, G., Lanari, R., Zeni, G., Guzzetti, F.: Spaceborn Radar Interferometry for Landslide Monitoring, The First Italian Workshop on Landslides, Rainfall - Induced Landslides, Napoli, pp. 138-144, 2009.

[15] Tarchi, D., Casagli, N., Fanti, R., Leva David, D., Luzi, G., Pasuto, A. Pieraccini, M., Silvano, S.: Landslide Monitoring by Using Groundbased SAR Interferometry: an Example of Application to the Tesina Landslide in Italy, Engineering geology, 68, pp. 15-30, 2003.

[16] Canuti, P., Casagli, N., Catani, F., Falorni, G., Farina, P.: Integration of Remote Sensing Techniques in Different Stages of Landslide Report (Chapter 18), Progress in Landslide Science, eds. $\mathrm{K}$. Sassa, H. Fukuoka, F. Wang \& G. Wang, Springer-Verlag Berlin Heidelberg, pp. 251-260, 2007.
[17] Shao-tang, L., Zhi-wu, W.: Choice of surveying methods for landslide monitoring, Proc. of the 10th International Symposium on Landslides and Engineered Slopes, Xi'an, pp. 1211-1216, 2008.

[18] Yen, J., Chen, K., Chang, C., Boerner W.: Evaluation of earthquake potential and surface deformation by Differential Interferometry, Remote Sensing of Environment, 112, pp. 782-795, 2008.

[19] Jaboyedoff, M., Oppikofer, T., Abellan, A., Derron, M., Loye, A., Metzger, R., Pedrazzini, A.: Use of LIDAR in landslide investigations: a review, Nat Hazards, 61, pp. 5-28, 2012.

[20] Gajski, D., Fiedler, T., Krtalić, A.: Classification and Filtering of Airborne Topographic LIDAR Data. The international archives of the photogrammetry, remote sensing and spatial information sciences, 34, pp. 100-104, 2003.

[21] Kraus, K., Pfeifer, N.: Determination of terrain models in wooded areas with airborne laser scanning data, SSPRS Journal of Photogrammetry and Remote Sensing, 53, pp. 193-203, 1998.

[22] Brúckl, E., Brunner, F.K., Kraus, K.: Kinematics of Deep-seated Landslides Derived from Photogrammetric, GPS and Geophysical Data, Engineering Geology, 88 (3-4), pp. 149-159, 2006.

[23] Ortolan, Ž., Mihalinec, Z., Stanić, B., Pleško, J.: Application of Repeated Photogrammetric Measurements at Shaping Geotechnical Models of Multi-layer Landslides, Proc. of the 6th Int. Symposium on Landslides, Christchurch, pp.1685-1691, 1992.

[24] US Army Corps of Engineers: Structural Deformation Surveying (EM 1110-2-1009), 292 p., Washington, 2002.

[25] Stanić, B., Ortolan, Ž., Mikulić, J., Mihalinec, Z.: Stanje klizišta Zalesina, Građevinar, 5, pp. 203-206, 1990.

[26] Nonveiller, E., Šuklje, L.: Landslide Zalesina, Geotechnique, 5, pp. 143-153, 1955.

[27] Cardellini, S., Osimani, P.: Living With Landslide: The Ancona Case History and Early Warning System, Open Workshop within the frame of EU FP7 'SafeLand' Project, Vienna, pp. 61-66, 2010.

[28] Gili, J.A., Corominas, J., Rius, J.: Using Global Positioning System Techniques in Landslide Monitoring, Engineering Geology, 55, pp. $167-192,2000$

[29] Dunnicliff, J.: Geotechnical Instrumentation for Monitoring Field Performance, John Wiley \& Sons, New York, 1988.

[30] Steiner, P., Yetman, R.: New Instruments Improve Site Characterization with Time Based Instruments, Proc. of the Regional Symposium of the ISRM, Eurock 2009, Cavtat, pp. 577582, 2009.

[31] Angeli, M.G., Pasuto, A., Silvano, S.: A Critical Review of Landslide Monitoring Experience, Engineering Geology, 55, pp. 133-147, 2000.

[32] Solexpert: Chain Deflectometer, Geotechnics Product List; http://www.solexperts.com (preuzeto 03.06.2013.)

[33] Damiano, E., Olivares, L., Minardo, A., Greco, R., Zeni, L., Picarelli, L.: Advanced monitoring criteria for precocious alerting of rainfall-induced flowslides, Proc. of the 10th International Symposium on Landslides and Engineered Slopes, Xi'an, pp. 1157-1163, 2008

[34] Shi, B., Sui, H., Zhang, D., Wang, B., Wei, G., Piao, C.: Distributive monitoring of the slope engineering, Proc. of the 10th International Symposium on Landslides and Engineered Slopes, Xi'an, pp. 1283-1288, 2008.

[35] Slope Indicator: Applications Guide, Second Edition, Slope Indicator Company, 1994. 
[36] Ortolan, Ž.: Formiranje prostornog inženjerskogeološkog modela dubokog klizišta s više kliznih ploha, Doktorski rad, Sveučilište u Zagrebu, Zagreb, 1996.

[37] Mikkelsen, P.E.: Advances in inclinometer Data Analysis, Proceedings of the 6th International Symposium on Field Measurements in Geomechanics, Oslo, pp. 555-567, 2003.

[38] Mihalinec, Z.: Sanacija klizišta "Grmoščica"- Zagreb, Glavni projekt radova prve etape sanacije, Zavod za geotehniku IGH, oznaka projekta 2230-1-220481/02-4R2, Zagreb, 2002.
[39] Mihalinec, Z.: Sanacija klizišta 'Grmoščica' - Zagreb, Monitoring klizišta nakon završetka l etape sanacije, Izvješče o provedenom monitoringu (listopad 2007.-studeni 2009.), Zavod za gospodarenje gradevinama, Institut IGH, broj evidencije 22305/10, Zagreb, 2010.

[40] Ortolan, Ž., Mihalinec, Z.: Sanacija klizišta "Grmoščica", Geotehnički elaborat s prijedlogom mjera sanacije, Knjiga 1 Inženjerskogeološki elaborat, Knjiga 3: Istražni radovi, Zavod za geotehniku IGH, oznaka evidencije 2230-1-213491/93, Zagreb, 1995. 